Board on "The Distribution and Seasonal Abundance of the Flat-fishes in the North Sea," by Dr. Fulton. This is also largely a statistical paper, and somewhat overlaps Henking's work in the North Sea and the Cattegat, and Dr. Heincke's, so far as flat-fishes are concerned. A main point is the "complementary and compensatory fluctuations" in the statistics, e.g. the "witch" or pole-dab in square xiv., near the Fair Isle, taking, during the winter, the place of dabs, lemon dabs, and plaice. Uncertainty, however, exists, as no other method of fishing than trawling was used on the same ground to make sure the other forms were not there. This condition is well known to fishermen. In regard to the maximum of the captures in each fish, it is found that it corresponds to the spawning season. While this paper likewise does not deal directly with the great question handed over to the Scotch Board to solve, it indirectly supports the "Resources of the Sea" in so far as the total average of lbs. per hour of fishing was greater (in flat-fishes) in 1903 than in rgor.

One of the most important papers is that of Dr. H. M. Kyle, who shows that the quantity of fish of all kinds landed in the North Sea ports, and especially of flat-fishes, was greater in 1903 than in 1902. This is clearly substantiated by Johansen's observations on Danish plaice. Hjort's work, again, removes any fear of diminution of round fishes for the supply of the North Sea.

While, therefore, the work of the British international observers up to date does not show an answer to the fundamental question submitted by the Government, yet it inadvertently supports the "Resources of the Sea," and is fairly compatible with the safety of the fishes in the North Sea. Finally, a separate English Fisheries Board, as Lord Dalhousie recommended, was suggested.

\section{NEW ZEALAND PETROGRAPHY.'}

THE first volume of this work was reviewed in NATURE of January 4, 1906, vol. 1xxili., gp. 234, 235. We noticed in that place the reasons which led to these Cape Colville rocks being selecyed for spelatudy, and also the circumstances putich necessary to call in extraneous fid for he acscriptive part of the work. Of the volume $\mathrm{n}$ w we use the first two-thirds, to which alone the ple of the book is properly applicable, completes the account of the volcanic rocks of the Cape Colville Peninsula. As before, the petrographical descriptions are by Prof. Sollas, and the notes relative to locality and occurrence by $\mathrm{Mr}$. McKay, who also furnishes a clear geological map of the district. The details of mineralogical composition and micro-structure do not include much that is new, though we may mention the occurrence of a felspar of the anorthoclase type in some of the rhyolites, the frequent association of hornblende (or its pseudomiorphs) with hypersthene in the andesitic rocks, and the presence of olivine in certain basic hypersthene-andesites or hypersthene-basalts. The interest of this collection of Tertiary andesites, dacites, and rhyolites lies, not so much in any novelty which they present, as in the close resemblance of the whole assemblage from this " petrographical province" to familiar types from better-known areas, such as Hungary and the Great Basin of North America.

The lack of arrangement and some minor blemishes, on which we will not insist, are drawbacks doubtless incidental to the conditions under which the work was carried out, by the cooperation of a petrologist in England with a field-geologist at the Antipodes. When this investigation was taken in hand, Mr. McKay, we believe, embodied in his own person the Geological Survey of New Zealand, and the work must be considered a notable production in these adverse circumstances. The re-organised Geological Survey, under the directorship of Dr. J. M. Bell, has begun operations with greater advantages, and two important memoirs of the new series have already appeared.

A special feature of the present work is the profusion of plates. This was not, we understand, a part of the

1 "The Rocks of Cape Colvil'e Peninsula, Aucklant, New Zealand." By Prof. Sollas. F.R.C. . with an. Introduction and Desrriotive Notes by Alexonder McKay. Vol. ii. Pr. 215 : with geological man and $\mathrm{r}_{33}$ photographic plates of rcck-sections. (Wellingtnn, N.Z. : J. McKay, 19c6.) No. I969, voL. 76] original design, but it greatly enhances the value of the book. In the two volumes more than two hundred fullpage plates are devoted to the illustration of the volcanic rocks of the Cape Colville Peninsula alone. The thin slices have been photographed with polarised light, usually with an amplification of sixty diameters, and most of the plates are very successful in rendering the micro-structure of the rocks selected. Such a collection of illustrations is welcome independently of the immediate object of the boak, and the fact that most of the rocks belong to types of world-wide distribution is, from this point of view, an advantage.

The latter part of this volume is devoted to the description and illustration of various rocks from numerous places in New Zealand. Some of these, from the Kaimanawa Mountains and other localities in the North Island, are volcanic rocks generally comparable with those of Cape Colville. Other descriptions are included here, without regard to relationship, to fill out the volume, and the want of any orderly arrangement gives a somewhat confused appearance to this section. Some remarkable teschenites are described from the east coast of Wellington Province. They appear to occupy the neck of an old volcano, and it is noteworthy that, like the similar rocks from some European localities, they are referred to a Cretaceous age. Special interest attaches to a collection of crystalline schists from Westland Province, on the west side of the South Island. In addition to garnetiferous mica-schists, epidote-amphibole-schists, and other ordinary types, there occurs a series of schistose ultrabasic rocks composed of serpentine, talc, tremolite, calcite, \&c. Through the same district there runs also a belt of massive ultrabasic rocks, viz. fresh and altered dunites. The geological relations of these two very interesting groups are only briefly touched in this work, but they are fully discussed in the first Bulletin (new series) of the Geological Survey, already mentioned.

Prof. Sollas's investigations, while devoted mainly to the exhaustive description of one group of rocks, afford also a glimpse of the rich variety of material which New Zealand offers to the petrographer. When we recall further the widely different " petrographical province" of Dunedin, characterised by highly alkaline rock-types, some of which have recently been described by Dr. Marshall, we may expect that a more comprehensive examination of the igneous and crystalline rocks of the colony will result in further important additions to petrological science.

A. $\mathrm{H}$.

\section{UNSOLVED PRCBLEMS IN THE DESIGN AND PROPULSION OF SHIPS. ${ }^{1}$}

THERE are but few problems in the design of ships, as in most other branches of engineering, that can be exactly or completely solved in the full scientific meaning of the word, and those are of a secondary character. The primary or fundamental problems of safety, strength, speed, and steadiness at sea are far too complicated to bring under anything like general mathematical treatment. The results obtained by the most advanced calculations cannot be applied directly to the real conditions of a ship at sea. After all is said and done, they merely relate to hypothetical cases which are simple in character and are amenable to mathematical treatment. Some of these calculations are very elaborate, and their elaboration may sometimes tend to magnify their importance. The real problem is often very imperfectly dealt with after they are made, and it can only be solved approximately for working purposes by accepting the results of calculation for what they may be really worth, judging of the allowances required for their incompleteness, and using them in a scientific way and a scientific spirit to arrive at safe conclusions. We are obliged to come to a conclusion somehow, because we have to build ships as well as we can, whether we can solve exactly all the problems that arise in their design or not;:and we have to take the responsibility of guaranteeing results, however difficult to obtain, or of decliring to do so, within the time allotted for the preparation of

1 Abridged from the "James Forrest" Lecture, delivered before the Institution of Civil Engineers on June 18, by Dr. Franicis Elgar, F.R.S. 